GRASAS Y ACEITES 70 (3)

July-September 2019, e320

ISSN-L: 0017-3495

https://doi.org/10.3989/gya.1055182

\title{
Textural properties, sensory acceptance and fatty acid profile of cooked meat batters employing pumpkin seed paste or soybean oil oleogel as fat replacers
}

\author{
B.M. Ferrer-González, I. García-Martínez and A. Totosaus ${ }^{\bowtie}$ \\ Food Science Lab \& Pilot Plant, Tecnológico Estudios Superiores Ecatepec. \\ Av. Tecnologico esq. Av. Central s/n, Ecatepec 55210, Mexico. \\ Corresponding author: atotosaus@tese.edu.mx
}

Submitted: 17 October 2018; Accepted: 12 December 2018; Published online: 9 May 2019

\begin{abstract}
SUMMARY: Oleogel from soybean oil and pumpkin seed paste were proposed as full replacements for pork backfat to decrease the saturated fat contents and improve the PUFA/SFA ratio in meat batters. Textural compression, along with shear and penetration tests provided similar information related to meat batter structure according to the type of fat, showing that a tougher but brittle texture was produced. Meat batters with fat replacers were darker and less red, but more yellow due to the incorporation of vegetable oil. Both hue angle $(\mathrm{H})$ and saturation index (S) values increased due to changes in color components, in addition to a higher total color difference compared to the control sample. Soybean oil oleogel increased the PUFA content considerably, maintaining a total fat content close to the control sample. Pumpkin seed paste increased PUFA but also reduced to caloric content due lower fat content. Consumers preferred pumpkin seed paste samples regardless of the color difference and lower fat content. Fat replacers employed to replace pork backfat substantially modified the fatty acid profile and decreased lipid oxidation with no detrimental effects on texture or acceptance.
\end{abstract}

KEYWORDS: Meat batters; Natural antioxidants; Saturated fats; Sensory acceptance; Texture; Unsaturated oils

RESUMEN: Propiedades texturales, aceptación sensorial y perfil de ácidos grasos de masas de carne cocida que emplean pasta de semillas de calabaza u oleogel de aceite de soja como sustitutos de la grasa. Se propone utilizar oleogel de aceite de soja o pasta de semillas de calabaza para reemplazar totalmente la grasa dorsal de cerdo en pastas cárnicas para disminuir el contenido de grasa saturada y mejorar la relación AGPI/AGS. Las pruebas de textura por compresión, tensión y penetración dieron la misma información sobre la estructura de los batidos cárnicos, de acuerdo con el tipo de grasa usado, demostrando que fue desarrollada una textura más dura pero menos cohesiva. Los batidos cárnicos con la grasa reemplazada fueron más oscuros y menos rojos, pero más amarillos debido a la incorporación de aceites vegetales. Los valores del ángulo de tono $(\mathrm{H})$ y del índice de saturación (S) se incrementaron debido a cambios en las coordenadas del color, además de presentar un valor mayor de diferencia total de color con respecto a la muestra control. Las muestras con oleogel de aceite de soja aumentaron considerablemente el contenido de AGPI, con un contenido total de grasa muy similar al de la muestra control. Las muestras con pasta de semillas de calabaza aumentaron también los AGPI, pero se disminuyó el contenido calórico al reducir el contenido de grasa. Los consumidores prefirieron las muestras con pasta de semillas de calabaza a pesar de la notoria diferencia de color y menor contenido de grasa. Los reemplazos de grasa dorsal de cerdo utilizados modificación substancialmente el perfil de ácidos grasos, disminuyeron la oxidación de lípidos, sin afectar la textura y la aceptación.

PALABRAS CLAVE: Aceites insaturados; Aceptación sensorial; Antioxidantes naturales; Grasas saturadas; Pastas cárnicas; Textura

ORCID ID: Ferrer-González BM https://orcid.org/0000-0001-6358-1189, García-Martínez I https://orcid.org/00000003-3582-0642, Totosaus A https://orcid.org/0000-0003-1965-9510

Citation/Cómo citar este artículo: Ferrer-González BM, García-Martínez I, Totosaus A. 2019. Textural properties, sensory acceptance and fatty acid profile of cooked meat batters employing pumpkin seed paste or soybean oil oleogel as fat replacers. Grasas Aceites 70 (3), e320. https://doi.org/10.3989/gya.1055182

Copyright: (02019 CSIC. This is an open-access article distributed under the terms of the Creative Commons Attribution 4.0 International (CC BY 4.0) License. 


\section{INTRODUCTION}

Meat and meat products are an important source of dietary fat, but sometimes with non-recommended polyunsaturated fatty acid/saturated fatty acid (PUFA/SFA) ratios. In this view, fat contents and lipid profiles must be changed to improve nutritional quality with the reformulation and/or diversification of meat products with health-promoting ingredients (Jiménez-Colmenero, 2007). Fats and oils supply energy and contain essential fatty acids that support the structural aspect of the body, providing substances that regulate physiological processes. Essential fatty acids such as linoleic and linolenic acids are metabolized eventually to provide eicosanoids, substances with hormone-like activity that regulate many bodily functions (Kritchevsky, 2002). Vegetable oils as plant derivatives contain natural antioxidants and antimicrobials that enhance the quality of meat products since major active components for antioxidant activity are polyphenols, flavonoids, phenolic diterpenes and tannins, delaying oxidation and microbial spoilage. They also enhance the blood lipids and decrease cholesterol (Hygreeva et al., 2014).

Strategies to improve the fatty acid profile generally entail replacement of the animal fat in product formulation with a different lipid, more in agreement with health recommendations to achieve a reduction in total fat (and energy content) or a reduction in cholesterol and modification of fatty acid profiles. Liquid phase oil stabilization and structuring (plastic fat which retains solid-like properties while possessing a healthier fatty acid profile) has recently been reported to develop fat alternatives to improve the quality of the reformulated meat products (Jimenez-Colmenero et al., 2015). Cellulose derivatives to incorporate restructured oil such as oleogel into meat products have the potential to allow for a customized formulation of texture and sensory characteristics to replace animal fat in emulsified meat products (Barbut et al., 2016). In the same manner, pumpkin seeds can be employed as a source of polyunsaturated oils and natural antioxidants. Since during cold-press, pumpkin oil maintains a higher total phenolic compound content (Siger et al., 2008), the ground seeds can be employed as a natural structured source of lipids with natural antioxidants. For example, pumpkin seed meal increased the cooking yield of Bologna-type sausages, with no effect on sensory properties (Mansour et al., 1996). Rivera-Ruiz and Totosaus (2011) employed pumpkin seed paste to improve the cooking yield and texture of pork sausages. In addition, ground pumpkin seeds were employed in the manufacture of chicken burgers, improving cooking and lipid stability during storage, with no effect on sensory quality attributes (Longato et al., 2017).
The objective of this work was to characterize the textural differences by compression (textural profile analysis), shear (Warner-Bratzler shear test) and incision (Meullenet-Owens razor shear test) of meat batters formulated with two fat replacers: pumpkin seed paste and soybean oil oleogel. In the same manner, instrumental color, changes in fatty acid profile, lipid stability and sensory acceptance were also determined.

\section{MATERIALS AND METHODS}

\subsection{Meat batters and fat replacer elaboration}

Lean pork and lard (pork backfat) were purchased from local abattoirs, removing visible fat and connective tissue. The meat $(50 \% \mathrm{w} / \mathrm{w})$ was ground through a $0.42-\mathrm{cm}$ plate in a meat grinder and mixed with salt $(2 \% \mathrm{w} / \mathrm{w})$, a commercial phosphate mixture (FABPSA, México City, $0.8 \% \mathrm{w} / \mathrm{w}$ ) and curing salt $(0.3 \% \mathrm{w} / \mathrm{w})$ with half of the total ice for two min in a Chef Prep 70610 Food Processor (Hamilton Beach, Glen Allen). Frozen lard (20\% in control sample) was added and emulsified for two more minutes. In two other elaborations, the lard was replaced with soybean oil oleogel or pumpkin seed paste. The rest of the ice was added and emulsified for 2-3 min, adding wheat flour $(5 \% \mathrm{w} / \mathrm{w})$ until the incorporation of all the ingredients, taking care to maintain the batter temperature at $12 \pm 2{ }^{\circ} \mathrm{C}$. The batters were stuffed into $20-\mathrm{mm}$ diameter cellulose casing and cooked in a water bath until reaching an internal temperature of $70 \pm 2{ }^{\circ} \mathrm{C}$ (about $15 \mathrm{~min}$ ), cooled in an ice bath and vacuum-packed and stored at $4{ }^{\circ} \mathrm{C}$ until subsequent analysis. A total of three batches of one kilo each from the treatments was manufactured with the same ingredients, formulation and technology on two different days.

Oleogel was elaborated with a mixture of ethyl cellulose (viscosity $100 \mathrm{cP}$, Sigma-Aldrich, St. Louis, USA), Avicel RC-591 (FMC Biopolymers, Philadelphia), and $\alpha$-cellulose (Sigma-Aldrich, St Louis), in 67.0:16.5:16.5 proportions (Totosaus et al., 2016). The celluloses mixture $(11 \%, \mathrm{w} / \mathrm{w})$ and $3.67 \%(\mathrm{w} / \mathrm{w})$ of Span ${ }^{\circledR} 60$ as surfactant were dissolved with $85.33 \%(\mathrm{w} / \mathrm{w})$ Nutrioli ${ }^{\circledR}$ soybean oil (Grupo Ragasa, Monterrey). The solution was heated at $120^{\circ} \mathrm{C}$ using a magnetic stirring hot plate at a constant rate for approximately $20-30 \mathrm{~min}$, until complete cellulose solubilization. After completion of the heating process, molten soybean oil oleogel was poured into beakers and cooled to room temperature before being stored (at least $24 \mathrm{~h}$ ) under refrigeration $\left(4 \pm 1^{\circ} \mathrm{C}\right)$.

Pumpkin seed paste was elaborated according to the methodology described by Rivera-Ruiz and Totosaus (2011). Hulled pumpkin seeds (Cucurbita pepo L.) were macerated in tap water overnight to remove the green cuticle. The soaked seeds were cold 
grounded to extract the oily phase in a manual seed mill. Whole ground cake was employed to increase fiber content. Finely ground seeds $(63 \%)$ were mixed with water $(32 \%, 2: 1$ proportion, w/v) and maize starch was added $(5 \%, \mathrm{w} / \mathrm{w})$ as plasticizer, and the mixture was stirred until obtaining a homogeneous paste (solid vegetable oil). The paste was then vacuum packed and stored under refrigeration.

\subsection{Textural characterization}

Meat batters samples from the three treatments were cut into $2-\mathrm{cm}$ lengths to perform a texture profile analysis (TPA), compressing axially in two consecutive cycles ( $50 \%$ original height) with a $40 \mathrm{~mm}$ diameter acrylic probe at a cross-head speed of one $\mathrm{mm} / \mathrm{s}$, waiting period of $5 \mathrm{~s}$, in a LFRA 4500 Texture Analyzer (Brookfield Engineering, Middleboro). From the force-time curves textural parameters were calculated as follows: hardness (force necessary to attain a given deformation, maximum force), cohesiveness (strength of the internal bonds making up the body of the product), springiness (the extent to which a product returns to its original shape when compressed) (Szczesniak, 1963, Bourne, 1978). Resilience (energy absorbed by the sample during compression and then released, during the first compression) was determined from force-deformation curves measuring the area enclosed by the hysteresis loop, i.e., energy stored in the sample that allows the recovery of its original shape to some extent (Voisey et al., 1975). Results are the mean of at least five reproducible runs for each treatment per batch.

Meat batter samples $(5 \mathrm{~cm}$ length) were shearcompressed with a Warner-Bratzler blade (TA-SBA, Brookfield Engineering, Middleboro) adapted to the same texture analyzer, at a constant crosshead speed rate of one $\mathrm{mm} / \mathrm{s}$. The Warner-Bratzler (WB) shear parameters were calculated from the force-deformation curves according to the procedure described by Veland and Torrissen (1999), as follows: fitting area (work required before sample breaks), breaking strength (peak force at the time when shearing begins, first significant peak), shear area (area during shearing, measuring the work performed during irrecoverable deformation), maximum shear force (highest peak detected during the test, after breaking strength), and total area (fitting area plus shear area, as the total amount of work required to cut through the sample). The results are the mean of at least five reproducible runs for each treatment per batch.

Meat batter samples $(4 \mathrm{~cm}$ length and $2 \mathrm{~cm}$ diameter) were perpendicularly incised to a $10 \mathrm{~mm}$ depth at a constant speed of $10 \mathrm{~mm} / \mathrm{s}$ and trigger force of $0.1 \mathrm{~N}$ for the Meullenet-Owens razor shear (MORS) test, employing a blade (narrow chisel knife blade \#17, $0.5 \mathrm{~mm}$-thick, $8.9 \mathrm{~mm}$-wide and $30 \mathrm{~mm}$-high) adapted to same texture analyzer. From the force-time curves the maximum shear force (highest peak force during shear test) and total shear energy (area under the shear curve) were calculated (Meullenet et al., 2004). The results are the mean of at least five reproducible runs for each treatment per batch.

\subsection{Instrumental color}

Instrumental meat batter color on CIE-Lab coordinates was determined by adapting the methodology reported by Yam and Papadakis (2004). Sample images were captured on a flatbed HP Photosmart Plus scanner (HP, Palo Alto) at a 600 dpi resolution. The images were converted to Lab color mode with Adobe Photoshop software. From the Image Histogram window the luminosity L*, redness $\mathrm{a}^{*}$ and yellowness $\mathrm{b}^{*}$ values were calculated and standardized according to equations (1), (2) and (3), as follows:

$$
\begin{gathered}
\text { Luminosity }\left(\mathrm{L}^{*}\right)=\frac{\text { Lightness }}{255} \times 100 \\
\text { Redness }\left(+\mathrm{a}^{*}\right)=\frac{240 \mathrm{a}}{255}-120 \\
\text { Yellowness }\left(+\mathrm{b}^{*}\right)=\frac{240 \mathrm{~b}}{255}-120
\end{gathered}
$$

In the same manner, from standardized lab values the hue angle and saturation index were calculated as described by Little (1975), according to equations (4) and (5), respectively, as:

$$
\begin{gathered}
\text { Hue angle }(H)=\operatorname{Tan}^{-1} \frac{b^{*}}{a^{*}} \\
\text { Saturation index }(S)=\sqrt{a^{* 2}+b^{* 2}}
\end{gathered}
$$

The total color difference (DE) between soybean oil oleogel or pumpkin seed paste samples, considering the control sample as reference (Cava et al., 2012), was calculated with equation (6), as:

$$
\text { Color difference }(\Delta E)=\sqrt{\begin{array}{l}
\left(\mathrm{L}_{\text {Control }}^{*}-\mathrm{L}^{*}\right)^{2}+ \\
\left(\mathrm{a}_{\text {Control }}^{*}-\mathrm{a}^{*}\right)^{2}+ \\
\left(\mathrm{b}_{\text {Control }}^{*}-\mathrm{b}^{*}\right)^{2}
\end{array}}
$$

\subsection{Fatty acid profile, total fat content and oxidative rancidity}

The fatty acid profile of each meat batter formulation was analyzed according to the AOAC Official Method 963.22. Fatty acid methyl esters 
were prepared according to the AOAC Official Method 969.33 (AOAC, 1999). The methyl esters of the fatty acids of the different samples were analyzed by employing a Hewlett Packard gas chromatographer (Palo Alto, CA, USA) with a Zebron ZB-WAX column $(30 \mathrm{~m} \times 0.32 \mathrm{~mm} \times 0.50 \mu \mathrm{m})$. The oven temperature was set at $120-190{ }^{\circ} \mathrm{C}$ to reach $225^{\circ} \mathrm{C}$ with a ramp rate of $12{ }^{\circ} \mathrm{C} / \mathrm{min}$, in a $60 \mathrm{~min}$ run, at 11.6 psi helium flow rate. Fatty acids were expressed as a percentage of total fatty acids identified and grouped as follows: saturated (SFA), monounsaturated (MUFA) and poly-unsaturated (PUFA) fatty acids. PUFA/SFA ratio was calculated as well.

The total fat content in the meat batter total fat content was determined in accordance with the AOAC Official Method 960.39, as ether extract (crude fat) (AOAC, 1999).

Oxidative rancidity in the meat batter samples was determined using the methodology modified by Zipser and Watts (1962). Ten g of ground sample were mixed with $49 \mathrm{~mL}$ of distilled water at $50{ }^{\circ} \mathrm{C}$, adding one $\mathrm{mL}$ of a sulfanilamide- $\mathrm{HCl}$ solution $(0.5 \%$ and $20 \%$, respectively, v/v). Subsequently, the sample was transferred to a $500 \mathrm{~mL}$ Erlenmeyer flask containing $48 \mathrm{~mL}$ of distilled water at $50{ }^{\circ} \mathrm{C}$ and $2 \mathrm{~mL}$ of $\mathrm{HCl}$ solution $(50 \% \mathrm{v} / \mathrm{v})$, plus 2 drops of silicone-based antifoam. The content of the flask was distilled for about 10-15 minutes or until obtaining $50 \mathrm{~mL}$ of distillate. An aliquot of $5 \mathrm{~mL}$ was taken and mixed with $5 \mathrm{~mL}$ of a thiobarbituric acid solution $(0.02 \mathrm{M}$ in glacial acetic acid $90 \%)$. Samples were placed in boiling water for $35 \mathrm{~min}$ utes, cooled and the absorbance was measured at $538 \mathrm{~nm}$. The concentration of malonaldehyde ( $\mathrm{mg} / \mathrm{kg}$ of sample) was calculated by extrapolating the absorbance against a 1,1,3,3-tetraethoxypropane $\left(3 \times 10^{3} \mathrm{~g} / \mathrm{L}\right)$ solution.

\subsection{Sensory acceptance}

Acceptability of the meat batters was rated using a $10 \mathrm{~cm}$ structured graphical hedonic scale marked with a far-left anchor of 'extremely unacceptable' and far-right anchor 'extremely acceptable' (Clark and Johnson, 2002). A total of 40 participants (25 $9 / 15{ }^{\lambda}$ in ages ranging from 20 to 45 ) were recruited from faculty members and students. No sensory training was provided prior to the evaluation sessions. Two samples (approximately 20-25 g) of control and fat replaced formulation (soybean oil oleogel or pumpkin seed paste) were presented and each sample was identified with a 3-digit random number. Panelists were informed that in one of the samples a vegetable origin fat was employed to replace the saturated animal fat. Each subject assessed one pair of samples within a period of two consecutive days at approximately the same time of day. Water was supplied to clean the palate between samples. The panelists were asked to rate, according to their personal preference, a position anywhere along the scale to match their perception of taste, color, texture, fat sensation and overall acceptance, during and after tasting the different samples. The ratings were converted to a numerical score based on the distance in $\mathrm{mm}$ from the far-left anchor of the scale. As criterion for acceptability the mean score was $\geq 5$, corresponding to the mid-point of the line scale (representing "neither acceptable nor unacceptable").

\subsection{Experimental design and data analysis}

The effect of the fat replacer on meat batter properties was evaluated with the following proposed model in equation (7), as:

$$
y=\mu+a+\epsilon
$$

where y represents the textural parameters (TPA, WB, MORS), color parameter ( $\left.\mathrm{L}^{*}, \mathrm{a}^{*}, \mathrm{~b}^{*}, \mathrm{H}, \mathrm{S}\right)$ or oxidative rancidity for the type of fat (lard as control, soybean oil oleogel or pumpkin seed paste); $\mu$ is the overall mean; $\alpha$ is the main effect of fat type; and $\in$ is the residual error assumed to be normally distributed with zero mean and variance $\sigma^{2}$ (Der and Everitt, 2001). The results were analyzed according to the PROC ANOVA procedure in the SAS Software v 8.0 (SAS System, Cary, NC, USA), determining significant differences between means by the Duncan means test as well.

Sensory acceptance results were analyzed using a paired t-test with the PROC TTEST applying the PAIRED statement and alpha $=0.05(95 \%$ confidence level).

\section{RESULTS}

\subsection{Textural characterization}

Results from the textural profile analysis, showed that the samples elaborated with pumpkin seed paste were significantly $(\mathrm{P}<0.05)$ harder than the control samples; whereas the soybean oil oleogel samples were softer. The cohesiveness of the samples containing pumpkin seed paste was significantly $(\mathrm{P}<0.05)$ lower than the rest of the treatments. Soybean oil oleogel resulted in significantly $(\mathrm{P}<0.05)$ higher springiness values, followed by pumpkin seed paste samples. The same behavior was observed for resilience, where soybean oil oleogel samples were significantly $(\mathrm{P}>0.05)$ more resilient than pumpkin seed paste or the control samples (Table 1).

In the Warner-Bratzler shear force test, pumpkin seed paste samples presented significantly $(\mathrm{P}<0.05)$ higher values for fitting area, followed by soybean oil oleogel samples. Both breaking strength and maximum force were significantly $(\mathrm{P}<0.05)$ higher for pumpkin seed paste samples. The control samples obtained the lowest values for both 
TABLE 1. Duncan's mean test for textural characteristics of cooked meat batters formulated with soybean oil oleogel or pumpkin seed paste as fat replacer ( $n=10$, mean \pm S.D.).

\begin{tabular}{|c|c|c|c|}
\hline \multirow[b]{2}{*}{ Textural test } & \multicolumn{3}{|c|}{ Treatment } \\
\hline & Control & Soybean oil oleogel & Pumpkin seed paste \\
\hline & \multicolumn{3}{|c|}{ Textural Profile Analysis } \\
\hline Hardness (N) & $29.9 \pm 2.2^{\mathrm{b}}$ & $27.0 \pm 1.1^{\mathrm{c}}$ & $49.20 \pm 3.1^{\mathrm{a}}$ \\
\hline Cohesiveness & $0.7009 \pm 0.03^{\mathrm{a}}$ & $0.6823 \pm 0.01^{\mathrm{b}}$ & $0.6655 \pm 0.01^{\mathrm{c}}$ \\
\hline Springiness & $0.780 \pm 0.16^{\mathrm{c}}$ & $0.812 \pm 0.02^{\mathrm{a}}$ & $0.789 \pm 0.01^{\mathrm{b}}$ \\
\hline \multirow[t]{2}{*}{ Resilience (N mm) } & $132.49 \pm 16.4^{\mathrm{c}}$ & $182.49 \pm 28.9^{\mathrm{a}}$ & $135.22 \pm 11.7^{\mathrm{b}}$ \\
\hline & \multicolumn{3}{|c|}{ Warner-Bratzler shear force } \\
\hline Fitting area $(\mathrm{N} \mathrm{s})$ & $45.15 \pm 9.34^{\mathrm{c}}$ & $52.80 \pm 4.58^{\mathrm{b}}$ & $57.09 \pm 9.35^{\mathrm{a}}$ \\
\hline Breaking strength $(\mathrm{N})$ & $8.24 \pm 1.25^{\mathrm{c}}$ & $8.33 \pm 1.58^{\mathrm{b}}$ & $10.40 \pm 2.03^{\mathrm{a}}$ \\
\hline Shear area $(\mathrm{N} \mathrm{s})$ & $141.60 \pm 43.5^{\mathrm{a}}$ & $117.23 \pm 14.9^{\mathrm{b}}$ & $112.09 \pm 25.9^{\mathrm{c}}$ \\
\hline Maximum shear force $(\mathrm{N})$ & $8.33 \pm 1.21^{\mathrm{c}}$ & $8.73 \pm 0.82^{\mathrm{b}}$ & $9.76 \pm 1.52^{\mathrm{a}}$ \\
\hline \multirow[t]{2}{*}{ Total area $(\mathrm{N} \mathrm{s})$} & $187.8 \pm 50.1^{\mathrm{a}}$ & $174.3 \pm 24.5^{\mathrm{b}}$ & $164.9 \pm 30.0^{\mathrm{c}}$ \\
\hline & \multicolumn{3}{|c|}{ Meullenet-Owens razor shear } \\
\hline Maximum shear force $(\mathrm{N})$ & $1.57 \pm 0.038^{\mathrm{c}}$ & $1.80 \pm 0.870^{\mathrm{b}}$ & $2.46 \pm 1.54^{\mathrm{a}}$ \\
\hline Total shear energy ( $\mathrm{N} \mathrm{s}$ ) & $15.42 \pm 8.1^{\mathrm{a}}$ & $12.68 \pm 4.5^{\mathrm{b}}$ & $11.35 \pm 0.6^{\mathrm{c}}$ \\
\hline
\end{tabular}

${ }^{\mathrm{a}, \mathrm{b}, \mathrm{c}}$ Means with the same letter in the same row are not significantly $(\mathrm{P}<0.05)$ different.

breaking strength and maximum force. Both shear area and total area in lard-containing samples (control) presented significantly $(\mathrm{P}<0.05)$ higher values, followed by soybean oil oleogel samples (Table 1).

In the Meullenet-Owens razor test, the control samples presented the significantly $(\mathrm{P}<0.05)$ lowest values for maximum shear force; whereas pumpkin seed paste obtained the highest values. The control samples resulted in significantly $(\mathrm{P}<0.05)$ higher values for total shear energy. Pumpkin seed paste obtained the lowest values for this parameter (Table 1).

\subsection{Instrumental color}

For instrumental color, meat batter luminosity was significantly $(\mathrm{P}<0.05)$ higher in the control samples, and the darker ones were those containing pumpkin seed paste. Lard replacement decreased the samples' redness. Significantly $(P<0.05)$ lower redness values were detected in the pumpkin seed paste samples. In contrast, yellowness was significantly $(\mathrm{P}<0.05)$ higher for pumpkin seed paste samples, and the lowest values were observed for the control. Hue angle was significantly $(\mathrm{P}<0.05)$ higher in pumpkin seed paste samples. For the saturation index, significantly $(\mathrm{P}<0.05)$ higher values were observed for the soybean oleogel samples. As compared to the control, the total color difference was higher for pumpkin seed paste samples than for soybean oleogel samples (11.26 compared to 5.15) (Table 2).

\subsection{Fatty acid profile, total fat content and oxidative rancidity}

As expected, the contents in both saturated and mono saturated fats were higher in the control samples, with similar values for samples containing soybean oleogel and pumpkin seed paste. A high polyunsaturated fat content was observed in soybean oil oleogel, due to the soybean oil composition. The control samples presented higher concentrations of C16, C18 and 20:2. Soybean oil oleogel samples presented lower concentrations for both $\mathrm{C} 16$ and C18 than pumpkin seed paste samples. The C18:1 content was similar in both pumpkin seed paste and control samples, with a lower content in the soybean oleogel samples. Nonetheless, the soybean oil oleogel meat batters presented higher C18:2 w-3 (linoleic acid) and C18:2 w-6 (gamma-linoleic acid) contents. The control samples presented the lowest C20:4 w-6 (arachidonic acid) content, but the highest C20:2 w-6 (eicosadienoic acid) content. C10 and C17 were absent from the pumpkin seed paste samples. In the control samples, formulated with pork backfat lard, the main identified fatty acids in decreasing order of concentration were: oleic, palmitic, linoleic, stearic and palmitoleic. The main identified fatty acids in the soybean oleogel samples were: linoleic, oleic, palmitic, stearic and linolenic. For samples with pumpkin seed paste the main fatty acids were: oleic, linoleic, palmitic, stearic and palmitoleic. The total fat content was lower in pumpkin seed paste samples $(8.28 \%$, ether extract), and similar in both 
TABLE 2. Duncan's mean test for instrumental color of cooked meat batters formulated with soybean oil oleogel or pumpkin seed paste as fat replacer $(n=10$, mean \pm S.D. $)$.

\begin{tabular}{lccc}
\hline & \multicolumn{3}{c}{ Treatment } \\
\cline { 2 - 4 } Color parameters & Control & Soybean oil oleogel & Pumpkin seed paste \\
\hline Luminosity $\left(\mathrm{L}^{*}\right)$ & $74.55 \pm 3.25^{\mathrm{a}}$ & $70.78 \pm 2.89^{\mathrm{b}}$ & $64.87 \pm 1.97^{\mathrm{c}}$ \\
Redness $\left(+\mathrm{a}^{*}\right)$ & $9.84 \pm 0.87^{\mathrm{a}}$ & $9.46 \pm 1.01^{\mathrm{b}}$ & $6.06 \pm 0.93^{\mathrm{c}}$ \\
Yellowness $\left(+\mathrm{b}^{*}\right)$ & $3.95 \pm 0.55^{\mathrm{c}}$ & $7.44 \pm 0.61^{\mathrm{b}}$ & $8.31 \pm 0.76^{\mathrm{a}}$ \\
Hue angle (H) & $0.382 \pm 0.05^{\mathrm{c}}$ & $0.667 \pm 0.06^{\mathrm{b}}$ & $0.941 \pm 0.10^{\mathrm{a}}$ \\
Saturation index (S) & $10.61 \pm 1.35^{\mathrm{b}}$ & $12.04 \pm 1.95^{\mathrm{a}}$ & $10.28 \pm 1.87^{\mathrm{b}}$ \\
Total color difference (DE) & - & 5.15 & 11.26 \\
\hline
\end{tabular}

${ }^{a, b, c}$ Means with the same letter in the same row are not significantly $(\mathrm{P}<0.05)$ different.

TABLE 3. Fatty acid composition ( $\%$ total fatty acids of total lipids) and total fat content (\%) for cooked meat batters formulated with soybean oil oleogel or pumpkin seed paste as fat replacer.

\begin{tabular}{lccc}
\hline & \multicolumn{3}{c}{ Treatment } \\
\cline { 2 - 4 } Fatty acids & Control & Soybean oil oleogel & Pumpkin seed paste \\
\hline Capric C10:0 & 0.070 & 0.028 & 0.000 \\
Lauric C12:0 & 0.067 & 0.034 & 0.102 \\
Myristic C14:0 & 1.150 & 0.432 & 0.829 \\
Palmitic C16:0 & 22.044 & 14.138 & 19.779 \\
Palmitoleic C16:1 & 1.802 & 0.786 & 1.621 \\
Margaric C17:0 & 0.180 & 0.134 & 0.000 \\
Stearic 18:0 & 11.191 & 5.656 & 8.767 \\
Oleic C18:1 n-9 & 41.834 & 28.203 & 43.777 \\
Linoleic 18:2 n-6 & 20.038 & 44.302 & 23.921 \\
Linolenic 18:2 n-3 & 0.650 & 5.647 & 0.457 \\
Arachidonic 20:4 n-6 & 0.182 & 0.240 & 0.277 \\
Eicosadienoic 20:2 n-6 & 0.656 & 0.314 & 0.471 \\
Saturated fats (SFA) & 4.63 & 2.73 & 2.46 \\
Mono saturated fats (MUFA) & 5.88 & 3.87 & 3.80 \\
Poly unsaturated fats (PUFA) & 2.77 & 6.61 & 2.82 \\
PUFA/SFA ratio & 0.60 & 2.42 & 1.15 \\
Total crude fat (\%) & 13.28 & 13.21 & 8.28 \\
\hline
\end{tabular}

the control and soybean oleogel samples (13.28 and $13.21 \%$, respectively) (Table 3).

For lipid oxidation, the control samples presented significantly $(\mathrm{P}<0.05)$ higher rancidity values, with the concomitant increase in the malonaldehyde concentration during storage time. Lower rancidity values were observed for pumpkin seed paste samples (Table 4).

\subsection{Sensory acceptation}

The panelists assigned significantly $(\mathrm{P}<0.05)$ different scores for meat batters employing different fat replacers (Table 5a). The mean difference indicated that pumpkin seed paste samples were more highly accepted, whereas soybean oil oleogel samples were less accepted, as compared to the control sample. For color, no significant $(\mathrm{P}>0.05)$ differences were detected between the fat-replaced samples and the control (Table 5b). Significantly $(\mathrm{P}<0.05)$ lower scores were assigned for texture in the soybean oil oleogel samples (Table 5c). For the fat sensation attribute, there was no significantly difference $(\mathrm{P}>0.05)$ among the different meat batters (Table 5d). Finally, in overall acceptance, pumpkin seed paste samples obtained significantly $(\mathrm{P}<0.05)$ higher scores than the control samples. The overall acceptance between soybean oil oleogel samples and control samples were not significantly different $(\mathrm{P}>0.05)$ (Table 5e). 
TABLE 4. Duncan's mean test for malonaldehyde content ( $\mathrm{mg} \cdot \mathrm{kg}^{-1}$ of sample) as lipid rancidity for meat batters formulated with soybean oil oleogel or pumpkin seed paste as fat replacer $(n=2$, mean \pm S.D. $)$.

\begin{tabular}{lccc}
\hline & \multicolumn{3}{c}{ Treatment } \\
\cline { 2 - 4 } Storage time (days) & Control & Soybean oil oleogel & Pumpkin seed paste \\
\hline 1 & $3.73 \pm 0.08^{\mathrm{a}}$ & $1.38 \pm 0.09^{\mathrm{b}}$ & $0.81 \pm 0.07^{\mathrm{c}}$ \\
8 & $4.78 \pm 0.09^{\mathrm{a}}$ & $2.92 \pm 0.10^{\mathrm{b}}$ & $2.27 \pm 0.05^{\mathrm{c}}$ \\
15 & $5.02 \pm 0.12^{\mathrm{a}}$ & $3.97 \pm 0.06^{\mathrm{b}}$ & $2.51 \pm 0.06^{\mathrm{c}}$ \\
22 & $7.29 \pm 0.07^{\mathrm{a}}$ & $5.10 \pm 0.09^{\mathrm{c}}$ & $5.99 \pm 0.12^{\mathrm{b}}$ \\
\hline
\end{tabular}

a, b, c Means with the same letter in the same row are not significantly $(\mathrm{P}<0.05)$ different.

TABLE 5. Paired t-test for sensory acceptability ratings of meat batters formulated with soybean oil oleogel or pumpkin seed paste as fat replacer $(n=40)$.

\begin{tabular}{|c|c|c|c|c|c|}
\hline & \multirow{2}{*}{$\begin{array}{c}\text { Mean score } \\
\text { (fat replaced) }\end{array}$} & \multirow{2}{*}{$\begin{array}{l}\text { Mean score } \\
\text { (control) }\end{array}$} & \multirow{2}{*}{$\begin{array}{c}\text { Mean difference } \\
\text { (fat replaced-control) }\end{array}$} & \multicolumn{2}{|c|}{$95 \%$ CI interval for difference } \\
\hline & & & & Lower & Upper \\
\hline \multicolumn{6}{|l|}{ (a) Taste } \\
\hline Pumpkin seed paste & 7.74 & 6.39 & $1.35 *$ & 0.621 & 2.065 \\
\hline Soybean oil Oleogel & 6.51 & 7.50 & $-0.99 *$ & -1.823 & -0.017 \\
\hline \multicolumn{6}{|l|}{ (b) Color } \\
\hline Pumpkin seed paste & 5.63 & 5.45 & 0.18 & -0.551 & 0.898 \\
\hline Soybean oil Oleogel & 5.87 & 5.70 & 0.17 & -0.473 & 0.799 \\
\hline \multicolumn{6}{|l|}{ (c) Texture } \\
\hline Pumpkin seed paste & 7.35 & 6.68 & 0.67 & -0.261 & 1.594 \\
\hline Soybean oil Oleogel & 6.45 & 7.35 & $-0.90 *$ & -1.659 & -0.008 \\
\hline \multicolumn{6}{|l|}{ (d) Fat sensation } \\
\hline Pumpkin seed paste & 7.53 & 6.57 & 0.96 & -0.551 & 0.898 \\
\hline Soybean oil Oleogel & 7.18 & 6.97 & 0.21 & -0.656 & 1.049 \\
\hline \multicolumn{6}{|l|}{ (e) Overall acceptance } \\
\hline Pumpkin seed paste & 7.51 & 6.61 & $0.90 *$ & 0.166 & 1.621 \\
\hline Soybean oil Oleogel & 6.47 & 6.92 & -0.45 & -1.283 & 0.430 \\
\hline
\end{tabular}

* Value for fat-replaced meat batter is significantly different $(\mathrm{P}<0.05)$ from control equivalent

\section{DISCUSSION}

\subsection{Textural characterization}

The results from the textural profile analysis indicated that when lard was replaced the texture depended on the type of fat replacer. Pumpkin seed paste, formulated with starch, resulted in a harder but less cohesive texture. In contrast, soybean oil oleogel, formulated with celluloses, resulted in a softer but more ductile and elastic texture. The different functional properties of starch and cellulose explain the differences in the developed texture during thermal processing. During the emulsified meat products thermal process, myofibrillar proteins are responsible for texture. The transition temperatures of meat proteins for the gelation of the meat batter protein matrix during the thermal process are well documented. Myofibrillar protein unfolding starts with myosin, in a first transition at $54-58^{\circ} \mathrm{C}$. The second transition occurs at $65-67^{\circ} \mathrm{C}$ and is assigned to collagen, sarcoplasmic proteins and actomyosin (Tornberg, 2005). On one hand, wheat starch gelatinization is divided into two stages, starting at around $60-70{ }^{\circ} \mathrm{C}$ with disruption of weakly bound proteins, and the subsequent rapid swelling between $80-90{ }^{\circ} \mathrm{C}$, involving the disruption of strong bonds (Olkku and Rha, 1978). The incomplete gelatinized starch absorbs more water than meat proteins, which begin to denature and gel before starch is gelatinized, enhancing the gel strength of the starch/meat composite ( $\mathrm{Li}$ and Yeh, 2002). This resulted in a harder and more rigid but less cohesive texture. On the other hand, the oleogel cellulose gelation mechanism 
does not involve a highly ordered secondary structure formation, displaying a unique thermo-reversible gelation mechanism (Davidovich-Pinhas et al., 2015). Cellulose increased the hydrophobicity of meat proteins by stabilizing fat encapsulation (Lin et al., 1988), reducing binding among meat particles, increasing the amount of free water, and hence decreasing hardness (Barbut and Mittal, 1996). This resulted in a softer meat batter texture.

In the Warner-Bratzler shear test, initial force (fitting area and breaking strength) could be correlated with the meat batter skin formed during the thermal process. Surface skin formation in cooked meat batter is associated with the migration and deposition of soluble muscle protein from the emulsified protein matrix to the surface (Mittal and Blaisdell, 1982). The Warner-Bratzler shear force test provides information about the structural components of meat -- forces detected before the maximum shear force (initial yield) are related to myofibrillar components, and subsequent forces are associated to connective tissue (Voisey, 1976). Beyond initial forces, maximum shear force and shear area (force and work necessary to cut internal meat batter structure during irrecoverable deformation) are associated with the cut through the sample before the skin is broken.

The replacement of lard decreased the work (force and energy) necessary to penetrate the samples with the blade. A razor blade can shear hard samples with great precision without compressing, since many foods are first sheared by the incisors when introduced into the mouth, and texture variations can be measured by slicing through the whole sample with blades (García-Segovia et al., 2014). Once again, initial opposition against blade penetration was offered by meat batter skin. The presence of skin confers higher integrity to the meat batter, and since it is subjected to a more severe thermal process than bulk internal material, skin acquires different resistance characteristics because of the different meat batter bulk properties (Guerra Daros et al., 2005).

Due to the anisotropic characteristics of the formulated meat batters, different bulk properties will result in different textural properties. The non-fat components of the fat replacers employed caused changes in the meat protein matrix structure. Pre-emulsified oils had the ability to create smaller fat particles than lard, with better distribution and meat protein tightly bound in the meat batter, generating higher cohesiveness values (Hu et al., 2016; Youseff and Barbut, 2010). In comparison with vegetable oils or fats, dorsal fat adipose tissue is harder and hence difficult to disintegrate and be dispersed homogeneously in the meat batters' protein matrix, since connective tissue in adipose tissue cell walls made them ticker and harder (Ranken, 2000). Pumpkin seed paste and soybean oil oleogel stabilize the lipid phase, affecting the development of the texture. Pumpkin seed paste resulted in harder but less cohesive samples, which resulted in a tougher structure which is more easily disintegrated. This corresponds to higher values for Warner-Bratzler maximum force (resistance to be sheared) and low total area, related to higher force but low shear energy in MORS.

\subsection{Instrumental color}

Pork backfat replacement in cooked meat batters resulted in color changes, where luminosity $\left(\mathrm{L}^{*}\right)$ was directly proportional to fat content: the higher the fat content, the lighter the coloration. When fat was reduced, samples became darker due to a reduction in overall light scattering associated with the scattering properties of fat (Pietrasik, 1999). Total fat content was relatively higher in control samples and soybean oil oleogel samples, with higher luminosity values. Pumpkin seed paste samples with lower fat content presented a darker coloration.

For soybean oil oleogel, color differences can be also attributed to the oil phase distribution within the protein matrix during processing, since vegetable fat is more uniformly dispersed than animal fat (Youseff and Barbut, 2010). On the other hand, fat replacement with vegetal fat decreased red tonality (Choi et al., 2009). This explains why the pumpkin seed paste samples were the least red ones. In the same manner, higher yellowness values for pumpkin seed paste samples were due to the carotenoid contents in pumpkin seeds (Nooe Aziah and Komathi, 2009). This color difference can be better appreciated in the different hue angle and saturation index values. Hue angle and saturation index indicate color variations and intensity, respectively. Both parameters were proposed to compensate for the major obstacle correcting the non-uniform spacing of the CIE-Lab diagram, comparing color differences throughout the space to reduce ambiguity (Little, 1975). The color tone differences (yellowness/redness ratio) were more marked in pumpkin seed paste samples, with higher hue angle values, probably because of the seed composition employed to elaborate the vegetable fat. In contrast, soybean oil oleogel, with a higher oil phase could be easily dispersed, thus enhancing the intensity of color (saturation index). The different texture of each fat (pork backfat or soybean oil oleogel or pumpkin seed paste) will result in a different dispersion pattern.

For overall color difference, DE indicates the degree of disagreement between two colors, where values higher than 6.0 are moderately disturbing, but when DE is ca. 12.0 there is a very prominent color difference (Saláková, 2012). Both samples with animal fat replacement presented higher color differences against the control sample, with a notorious color difference in pumpkin seed paste samples (close to 12). 


\subsection{Fatty acids profile, total fat content and oxidative rancidity}

Eating foods which maintain a PUFA/SFA ratio above 0.4 , replacing SFA with PUFA or MUFA is recommended for a healthy diet. In the present research, the use of vegetal fat replacers such as soybean oil oleogel or pumpkin seed paste increased the PUFA/SFA ratio (2.42 and 1.15 , respectively). In same manner, soybean oil oleogel with a higher oil phase maintained the amount of total fat, although with a noticeable decrease in its saturated fat content. Pumpkin seed paste decreased the amount of total fat since the oil phase was lower, but also incorporated an important amount of MUFA and PUFA.

Oxidation is another important quality index associated with chemical composition since it affects the fat's color and taste over time (Ospina et al., 2012). The chemical composition of pumpkin seed oil and soybean oil enhanced the oxidative stability of the meat batters. The pumpkin seeds' lipid-soluble bioactive compounds enhanced oxidative stability (Nyam et al., 2009; Kim et al., 2012). Since most phenolic acids were present in higher amounts in hulled pumpkin seeds, just below the content in oil cake meal (Pierčin et al., 2009), the use of the whole pumpkin seeds increased the phenolic compound content.

Soybean oil maintains its original amount of antioxidant compounds to a large extent, like $\alpha$-, $\gamma$-, $\delta$-tocopherol, and $\beta$-carotene (Tuberoso et al., 2007), decreasing frankfurters' oxidation due to the content in natural antioxidants.

\subsection{Sensory acceptation}

Despite the differences in fat content and fatty acid composition, consumers showed a preference for taste and texture, and even overall acceptance (with scores above 7.0, in the 'extremely acceptable' side) for the samples containing pumpkin seed paste, followed by the soybean oil oleogel samples. Fat as food ingredient is responsible of the characteristic flavor and texture in many food products, since it is related to pleasant food quality, although its consumption is restricted for nutritional reasons, so there is a high demand for low-fat meat products. As high fat content is associated with pleasant foods, less fat could mean less pleasure for consumers, and the effect of information about low fat content on low expected fattiness is logical, since juiciness and saltiness (taste and texture attributes) are not necessarily related to fat content (Kähkönen and Tourila, 1998).

In all the evaluated attributes the mean scores were above 5. Only color had the lowest scores, near 5 , in the middle of the hedonic scale, in agreement with the instrumental color differences detected. Although the pumpkin seed paste samples presented a noticeable color difference with respect to the control sample, all the samples obtained close values. The use of vegetable oils as fat replacers in meat batters resulted in no noticeable changes in color from the consumers' point of view, even when samples presented lower color scores (sensory and instrumental) (Câmara and Pollonio, 2015). Differences of the mean ratings of fat-replaced samples were not lower than one rating category below the control sample, with minor values for the lower $95 \%$ confidence level for the mean differences (Clark and Johnson, 2002). The replacement of lard with pumpkin seed paste or soybean oleogel did not change the perception of such sensory attributes.

\section{CONCLUSIONS}

Pork backfat replacement with pumpkin seed paste resulted in a hard and brittle texture, tough to initial shear or cut, but with a softer internal structure. The three different textural tests provided similar information related to meat batters' structure according to the type of fat replacer employed, related to fat dispersion and the fat replacers' components (cellulose derivatives in soybean oil oleogel, starch in pumpkin seed paste). Soybean oil oleogel as fat replacer maintained approximately the same fat content, but with a noticeable change in the fatty acid profile. Pumpkin seed paste reduced the total fat content and improved polyunsaturated fatty acid contents as well. The replacement of pork backfat enhanced lipid oxidation stability, with lower rancidity values when pumpkin seed paste was employed to replace pork backfat. Color was also affected by the fat replacement, with darker and less red coloration, but with a more intense tonality (higher hue angle and saturation index values), besides a notorious instrumental color difference. Curiously, relatively higher preference or no differences were observed for the sensory acceptance of pumpkin seeds paste, in spite of the marked instrumental color difference and less fat content. In conclusion, the use of vegetable fat replacers like pumpkin seed paste or soybean oil oleogel is a good alternative to substantially modify the fatty acid profile of meat batters, with no detrimental effect on texture. If caloric content is measured, soybean oil oleogel maintained the fat content, but with a higher amount of polyunsaturated fatty acids. If less caloric content is desirable, pumpkin seed paste is the better option.

\section{ACKNOWLEDGMENTS}

This work was supported by the Tecnológico Nacional de México (TecNM), Mexico, into the project "Oleogel application in foods formulation", 497.17-PD. The authors wish to thank Mrs. Carolina Gomez-Franco for her assistance in sample analysis and Professor Bedolla-Perez for his advice during the writing of the manuscript. 


\section{REFERENCES}

AOAC 1999. Official Methods of Analysis of AOAC International (16th ed). Washington D.C.: AOAC International.

Barbut S, GS Mittal. 1996. Effects of three cellulose gums on the texture profile and sensory properties of low fat frankfurters. Int. J. Food. Sci. Technol. 31, 241-247. https://doi. org/10.1046/j.1365-2621.1996.00337.x

Barbut S, Wood J, Marangoni A. 2016. Potential use of organogels to replace animal fat in comminuted meat products. Meat Sci. 122, 155-162. https://doi.org/10.1016/j.meatsci. 2016.08.003

Bourne MC. 1978. Texture Profile Analysis. Food Technol. 32, 62-66, 72 .

Câmara AKFI, Pollonio MAR. 2015. Reducing animal fat in bologna sausage using pre-emulsified linseed oil: technological and sensory properties. J. Food Quality 38, 201-212. https://doi.org/10.1111/jfq. 12136

Cava R, Landero L, Cantero V, Ramírez MR. 2012. Assessment of different dietary fibers (tomato fiber, beet root fiber, and inulin) for the manufacture of chopped cooked chicken products. J. Food Sci. 77, C346-C352. https://doi. org/10.1111/j.1750-3841.2011.02597.X

Choi Y-S, Choi J-H, Han D-J, Kim H-Y, Lee M-A, Kim H-W, Jeong J-Y, Kim C-J. 2009. Characteristics of low-fat meat emulsion systems with pork fat replaced by vegetable oils and rice bran fiber. Meat Sci. 82, 266-271. https://doi. org/10.1016/j.meatsci.2009.01.019

Clark R, Johnson S. 2002. Sensory acceptability of foods with added lupin (Lupinus angustifolius) kernel fiber using pre-set criteria. J. Food Sci. 67, 356-362. https://doi. org/10.1111/j.1365-2621.2002.tb11410.x

Davidovich-Pinhas M, Barbut S, Marangoni AG. 2015. The gelation of oil using ethyl cellulose. Carbohyd. Polym. 117, 869-878. https://doi.org/10.1016/j.carbpol.2014.10.035

Der G, Everitt BS. 2001. A Handbook of Statistical Analyses using $S A S$. Chapman \& Hall/CRC, London, pp. 101-116.

García-Segovia P, Pagán-Moreno MJ, Martínez-Monzó J. 2014. Texture in meat and fish products, Chapter 4 in Cruz RMS, Khmelinskii I, Vieira MC (Eds.). Methods in Food Analysis. CRC Press, Boca Raton, pp 76-109.

Guerra Daros F, Campos Amico S, Masson ML. 2005. A methodology for the evaluation of mechanical properties of sausages based on tensile and compression tests. Int. J. Food Eng. 1. https://doi.org/10.2202/1556-3758.1012

Hu H-Y, Pereira J, Xing L-J, Hu Y-Y, Qiao C-L, Zhou G-H, Zhang WG. 2016. Effects of regenerated cellulose emulsion on the quality of emulsified sausage. LWT-Food Sci. Technol. 70, 315-321.

Hygreeva D, Pandey MC, Radhakrishna K. 2014. Potential applications of plant based derivatives as fat replacers, antioxidants and antimicrobials in fresh and processed meat products. Meat Sci. 98, 47-57. https://doi.org/10.1016/j. meatsci.2014.04.006

Jiménez-Colmenero F. 2007. Healthier lipid formulation approaches in meat-based functional foods Technological options for replacement of meat fats by non-meat fats. Trends Food. Sci. Technol. 18, 567-578. https://doi.org/ 10.1016/j.tifs.2007.05.006

Jimenez-Colmenero F, Salcedo-Sandoval L, Bou R, Cofrades S, Herrero AM, Ruiz-Capilla C. 2015. Novel applications of oil-structuring methods as a strategy to improve the fat content of meat products. Trend Food. Sci. Technol. 44, 177-188. https://doi.org/10.1016/j.tifs.2015.04.011

Kähkönen, P, Tourila H. 1998. Effect of reduced-fat information on expected and actual hedonic and sensory ratings of sausage. Appetite 30, 13-23. https://doi.org/10.1006/ appe.1997.0104

Kim MY, Kim EJ, Kim Y-N, Choi C, Lee B-H. 2012. Comparison of the chemical composition and nutritive values of various pumpkin (Cucurbitaceae) species and parts. Nutr. Res. Pract. 6, 21-27. https://doi.org/10.4162/nrp.2012.6.1.21

Kritchevsky D. 2002. Fats and oils in human health, in Akoh CC, Min DB (Eds.). Food Lipids: Chemistry, Nutrition, and Biotechnology, 2nd ed. Marcel Dekker, New York, pp. 461-472.
Li J-Y, Yeh A-I. 2002. Functions of starch in formation of starch/ meat composite during heating. J. Texture Stud. 33, 341-366. https://doi.org/10.1111/j.1745-4603.2002.tb01353.x

Lin KC, Keeton JT, Gilchrist CL, Cross HR. 1988. Comparisons of carboxymethyl cellulose with differing molecular features in low-fat frankfurters. J. Food Sci. 53, 1592-1595. https://doi.org/10.1111/j.1365-2621.1988.tb07792.x

Little AC. 1975. Off on a tangent. J. Food Sci. 40, 410-411. https://doi.org/10.1111/j.1365-2621.1975.tb02213.x

Longato E, Lucas-González R, Peiretti PG, Meineri G, PérezÁlvarez JA, Viuda-Martos M, Fernández-López J. 2017. The effect of natural ingredients (amaranth and pumpkin seeds) on the quality properties of chicken burgers. Food Bioprocess. Tech. 10, 2060-2068. https://doi.org/10.1007/ s11947-017-1978-0

Mansour EH, Dworschák E, Huszka T, Hóvári J, Gergely A. 1996. Utilization of pumpkin seed and rapeseed proteins in the preparation of Bologna type sausages. Acta Aliment. Hung. 25, 25-36.

Meullenet J-F, Jonville E, Grezes D, Owens CM. 2004. Prediction of the texture of cooked poultry Pectoralis major muscles by near-infrared reflectance analysis of raw meat. J. Texture Stud. 35, 573-585. https://doi.org/10.1111/ j.1538-7836.2004.01165.x-i1

Mittal GS, Blaisdell JL. 1982. Moisture mobility in frankfurter during thermal processing: analysis of moisture profile. J. Food Process. Pres. 6, 111-126. https://doi. org/10.1111/j.1745-4549.1982.tb00646.x

Noor Aziah AA, Komathi CA. 2009. Physicochemical and functional properties of peeled and unpeeled pumpkin flour. J. Food Sci. 74, S328-S333. https://doi. org/10.1111/j.1750-3841.2009.01298.x

Nyam KL, Tan CP, Lai OM, Long K, Man YBC. 2009. Physicochemical properties of bioactive compounds of selected seed oils. LWT-Food Sci. Technol. 42, 1396-1403. https://doi.org/10.1016/j.lwt.2009.03.006

Olkku J, Rha C. 1978. Gelatinisation of starch and wheat flour starch -A review. Food Chem. 3, 293-317.

Ospina-E JC Sierra-C A Ochoa O, Pérez-Álvarez JA, FernándezLópez J. 2012. Substitution of saturated fat in processed meat products: A review. Crit. Rev. Food Sci. Nutrit. 52, 113-122. https://doi.org/10.1080/10408398.2010.493978

Pierčin D, Krimer V, Trivić S, Radulović L. 2009. The distribution of phenolic acids in pumpkin's hull-less seed, skin, oil cake meal, dehulled kernel and hull. Food Chem. 113, 450-456. https://doi.org/10.1016/j.foodchem.2008.07.079

Pietrasik Z. 1999. Effect of content of protein, fat and modified starch on binding textural characteristics and color of comminuted scalded sausages. Meat Sci. 51, 17-25. https:// doi.org/10.1016/S0309-1740(98)00068-0

Ranken MD. 2000. Handbook of Meat Product Technology. Blackwell Science Ltd, Oxford, pp. 13-18.

Rivera-Ruiz IN, Totosaus A. 2011. Sustitución de grasa animal por una manteca de semilla de calabaza en batidos cárnicos. Ing. Agríc. Biosist. 3, 11-16.

Saláková A. 2012. Instrumental measurement of texture and color of meat and meat products. Maso Int. 2, 107-114.

Siger A, Nogala-Kalucka M, Lampart-Szczapa E. 2008. The content and antioxidant activity of phenolic compounds in cold-pressed plant oils. J. Food. Lipids 12, 137-149. https:// doi.org/10.1111/j.1745-4522.2007.00107.x

Szczesniak AS. 1963. Classification of Textural Characteristics. J. Food Sci. 28, 385-389. https://doi.org/10.1111/j.13652621.1963.tb00215.x

Tornberg E. 2005. Effects of heat on meat proteins-Implications on structure and quality of meat products. Meat Sci. 70, 493-508. https://doi.org/10.1016/j.meatsci.2004.11.021

Totosaus A, González-González R, Fragoso M. 2016. Influence of the type of cellulosic derivatives on texture, oxidative and thermal stability of soybean oil oleogel. Grasas Aceites 67, e152. https://doi.org/10.3989/gya.0440161

Tuberoso CIG, Kowalczyk A, Sarritzu E, Cabras P. 2007. Determination of antioxidant compounds and antioxidant activity in commercial oilseeds for food use. Food Chem. 103, 1494-1501. https://doi.org/10.1016/j.foodchem. 2006.08 .014 
Veland J, Torrissen O. 1999. The texture of Atlantic salmon (Salmo salar) muscle as measured instrumentally using TPA and Warner-Bratzler shear test. J. Sci. Food Agric. 79, 1737-1746. https://doi.org/10.1002/(SICI)1097-0010 (199909)79:12<1737::AID-JSFA432>3.0.CO;2-Y

Voisey PW, Randall C, Larmond E. 1975. Selection of an objective test of wiener texture by sensory analysis. Can. Inst. Food Sci. Technol. J. 8, 23-29. https://doi.org/10.1016/ S0315-5463(75)73697-0

Voisey PW. 1976. Engineering assessment and critique of instruments used for meat tenderness evaluation. J. Texture Stud. 7, 11-48. https://doi.org/10.1111/j.1745-4603.1976.tb01380.x
Yam KL, Papadakis SE. 2004. A simple digital imaging method for measuring and analyzing color of food surfaces. J. Food Eng. 61, 137-142. https://doi.org/10.1016/ S0260-8774(03)00195-X

Youssef MK, Barbut S. 2009. Effects of protein level and fat/ oil on emulsion stability, texture, microstructure and color of meat batters. Meat Sci. 82, 228-233. https://doi. org/10.1016/j.meatsci.2009.01.015

Zipser M, Watts B. 1962. A modified 2-tiobarbituric acid (TBA) method for the determination of malonaldehyde in cured meats. Food Technol. 17, 102-104. 